\title{
SUSCEPTIBILITY OF PEPPER WEEVIL (ANTHONOMUS EUGENII CANO) (COLEOPTERA: CURCULIONIDAE) TO SEVEN INSECTICIDES IN RURAL AREAS OF BAJA CALIFORNIA SUR, MEXICO
}

\author{
Rosalía SERVín-VILlegas', José. L. García-HernándeZ1, \\ Armando Tejas-Romero', José L. Martínez-CarriLlo ${ }^{2}$ and, M. A. TOAPANTA ${ }^{3}$ \\ ${ }^{1}$ Centro de Investigaciones Biológicas del Noroeste, S.C. Mar Bermejo 195, Col. Playa \\ Palo de Santa Rita, Apdo. Post. 128. La Paz, B. C. S. CP: 23090. MÉXICO. \\ rservin04@cibnor.mx, jlgarcia04@cibnor.mx. \\ 2 INIFAP-CIRNO-Campo Experimental Valle del Yaqui \\ 3 Bayer Crop Science, 809 E. Bloomingdale Ave. Brandon, Florida. 33511. USA.
}

\begin{abstract}
RESUMEN
Se determinó la susceptibilidad a siete insecticidas del picudo del chile (Anthonomus eugenii) colectado en Baja California Sur, México. Para obtener la concentración letal cincuenta $\left(\mathrm{CL}_{50}\right)$ y la concentración de diagnóstico $\left(\mathrm{CL}_{95}\right)$ se utilizó la exposición residual de contacto con insecticidas organofosforados (OF), carbamatos (CA), piretroides (PIR) y organoclorados (OC), usados para el control de picudo del chile en dos áreas agrícolas (Los Planes y Todos Santos) en el Sur de la Península de Baja California, así como en una población del picudo del chile libre de insecticidas por dos años (PWIF). Los valores más elevados de $\mathrm{CL}_{50}$ se obtuvieron con metomil (CA) y oxamil (CA), seguidos por metamidofós $(\mathrm{OF})$, endosulfán $(\mathrm{OC})$, ciflrutín (PIR) y azinfós metílico $(\mathrm{OF})$. Los valores menores se observaron con carbaril (CA). La población de Todos Santos mostró menor susceptibilidad que la población de Los Planes a insecticidas como metomil, oxamil y carbaril; mientras que en metamidofós, azinfós metílico y ciflutrín los valores de las $\mathrm{CL}_{50}$ fueron más elevados. $\mathrm{PWIF}$ presentó las $\mathrm{CL}_{50}$ de menor valor, aunque las diferencias no fueron significativas con respecto a las dos poblaciones de campo, por lo que se considera necesario mantenerla libre de insecticidas durante un periodo mayor, para obtener una línea base susceptible de referencia para Anthonomus eugenii.
\end{abstract}

Palabras clave: Picudo del chile, Anthonomus eugenii, susceptibility, Baja California Sur, México.

\begin{abstract}
The susceptibility of the pepper weevil (Anthonomus eugenii), collected from Baja California Sur, Mexico, to seven insecticides was determined. A contact, residual exposition method was used to obtain the lethal concentrations fifty $\left(\mathrm{LC}_{50}\right)$ and the diagnostic concentration $\left(\mathrm{LC}_{95}\right)$ of organophosphates $(\mathrm{OF})$, carbamates (CA), pyrethroids (PIR), and organochlorine (OC) insecticides used to control pepper weevils from two agricultural areas (Los Planes and Todos Santos) in Southern Baja California Peninsula, as well as on a pepper weevil population not exposed to insecticides (PWIF) for two years. The highest $\mathrm{LC}_{50}$ 's were obtained for methomyl (CA) and oxamyl (CA), followed by methamidophos (OF), endosulfan (OC), cyfluthrin (PIR) and azinphos-methyl (OF). The lowest $\mathrm{LC}_{50}$ 's were observed for carbaryl (CA). The field population from Todos Santos showed lower susceptibility than the population from Los Planes to insecticides as methomyl, oxamyl, and carbaryl, while with
\end{abstract}


methamidophos, azinphos-methyl, and cyfluthrin, the $\mathrm{LC}_{50}$ showed higher values. The PWIF population presented the lowest $\mathrm{LC}_{50}$ values of all three populations tested. However, in most cases, the difference was not significant in relation to the two field populations, thus the PWIF population needs to be kept free of insecticides for longer periods to establish a susceptibility baseline for Anthonomus eugenii.

Key words: peeper weevil, Anthonomus eugenii, susceptibility, Baja California Sur, México.

\section{INTRODUCTION}

Pepper is one of the most important crops in some regions of India, China, Mexico, and the United States, among others. In Mexico, this crop occupies second place among commercial vegetables for export, and there are over 150,000 hectares cultivated per year (SAGARPA 2005). Pepper weevil (Anthonomus eugenii Cano) is the worst arthropod pest of all species and cultivars of pepper in the Southern United States, Mexico, Central America, and the Caribbean (Riley and King 1994, Toapanta et al. 2005). This pest attacks both pungent and mild peppers, causing economic losses ranging from 50 to $90 \%$ depending on the incidence level (PachecoCovarrubias 1985, Bernot 1992, Bujanos 1993, Gutierrez 1999). Pepper weevil cause floral buds and fruits to fall, and darkening or yellowing of fruits (Laborde and Pozo 1982, Bujanos 1993). The major damage is caused by the larvae, which feed inside immature fruits on seeds and placenta. In addition, when the weevil larvae complete metamorphosis and the adults emerge from the fruits, they leave orifices that facilitate the entrance of pathogens and subsequent tissue decomposition. Another deleterious effect on mature fruit is the weevil's feeding and excretion leaving a dark spotting, thus reducing marketability (Cásseres 1980).

In spite of the arid climate in Baja California Sur (BCS), pepper is one of the most successful crops, and constitutes an important source of rural employment. Records for the period 1993 to 1997 showed that an average of 1,600 ha per year was cultivated in this state, with production of 28,700 $\mathrm{t}$, and an economic value of seven million dollars. However, the yearly economic losses caused by pepper weevil during the 1996 - 1997 crop season were estimated at about one million dollars (SAGAR 1997).

Controlling pepper weevil has been a challenge to growers due to the lack of efficient natural enemies, resistant cultivars, and difficulties in timely application of insecticides (Riley 1995, Toapanta 2001). Growers frequently spray broad spectrum insecticides at the wrong timing, with no real benefits in controlling weevils.

In Mexico and the United States, chemical control is one of the most important tactics in managing pepper weevil, in spite of increasing restrictions for trading products contaminated with insecticides in international markets (Frantz and Mellinger 1998, Servín et al. 2002). Although a few field evaluations to determine the efficacy of different insecticides in combating pepper weevil have been conducted (Hernández and González 1992, Pacheco-Covarrubias 1993, Enríquez and Valenzuela 1996), there is still a lack of information about the susceptibility of this 
pest to insecticides (Quiñones and Flores 1991, López 1996). With the aim of contributing to better management of the pepper weevil, we studied two field populations of pepper weevils from growing areas of BCS, and a population with no exposure to insecticides. Such situation has a great relevance especially in arid agricultural systems, like BCS where a great percentage of farmers growing peppers use pesticides as the principal strategy to reduce pest damage. This work partially fills the gap on the knowledge of susceptibility levels of $A$. eugenii to widely used pesticides in this area.

\section{MATERIALS AND METHODS}

Weevil populations. We carried out toxicological tests on two field populations of pepper weevil, obtained from two major pepper growing areas in BCS, where the conventional use of insecticides is common. The study also included a population of weevils that was kept isolated from insecticides during two years (PWIF), at the Experimental Field of the Centro de Investigaciones Biologicas del Noroeste (CIBNOR) in La Paz, BCS. PWIF was originally collected from field populations from Todos Santos, BCS. The two field populations were collected from commercial pepper fields of the farming localities "Todos Santos" and "Los Planes" (At 23⒌ $109^{\circ} 59^{\prime} \mathrm{W}$ and $23^{\circ} 26^{\prime} \mathrm{N}, 110^{\circ} 13^{\prime} \mathrm{W}$, respectively), in BCS, both sown with the popular commercial cultivar "Ancho San Luis"; a mild pepper type "Poblano". These two fields are geographically isolated from each other by natural mountain barriers, xerophytic vegetation, and non-agricultural land. At each locality, 10 to $12 \mathrm{~kg}$ of fallen fruits were collected and deposited in plastic containers of $60 \mathrm{~cm}$ diameter and $25 \mathrm{~cm}$ depth, with a hard mesh to separate fruits from the container's bottom, and delay fruit deterioration (Capinera, 2005). Containers were covered with a $500 \mu$ screen, and kept ventilated at 25 to $34{ }^{\circ} \mathrm{C}$ and 60 to $70 \%$ relative humidity in the laboratory until the adult insects emerged. Weevils were collected from the plastic containers using a standard mouth-aspirator or "pooter" (Azrang 1976, Schauff 1986) and transferred to screened wooden cages of $25 \times 25 \times 40 \mathrm{~cm}$, where they were kept for 48 hours on a diet of fresh cut "Ancho San Luis" pepper fruits. In the same season, a pepper crop was established at the CIBNOR's experimental field in an isolated area of $5 \times 20 \mathrm{~m}$ to obtain the PWIF population described earlier. However, there is not robust evidence that this population effectively did not carry resistant genes.

Toxicological tests. Susceptibility of two-day old weevil adults was evaluated against seven of the most commonly used insecticides in northwest Mexico using a glass vial residual bioassay, previously published (Servín and Aguilar 2000). All insecticides assessed were of technical grade, including the carbamates carbaryl, methomyl and oxamyl; the organophosphate azinphos-methyl and metamidophos; the pyrethroid cyfluthrin, and the organochlorine endosulfan. 
Glass scintillation vials $(20 \mathrm{ml})$ were washed with liquid detergent and water, and rinsed once with acetone before treatments. A known quantity of each insecticide was dissolved in acetone and serially diluted to the desired dose. Five replicates of 5 to 8 different concentrations were used, depending on the population tested. The insecticide-acetone solution was placed in clean glass scintillation vials using a micropipette (Lab-systems; Helsinki, Finland) set at $1.0 \mathrm{ml}$. After addition of the solution, the vials were placed on a rolling machine (Star MFG International Hobson Line Smith, Mod 25, Ville Tennessee 37166). The vials were removed and capped after the acetone solvent was evaporated completely and the insecticide residue evenly distributed in the interior. Five unsexed adult insects were introduced into the vials, whose caps were modified to allow the weevils to breathe, and which were inverted to ensure continuous contact between the insects and the insecticide. Vials were held in the laboratory at $25 \pm 3{ }^{\circ} \mathrm{C}$, and relative humidity between $55-65 \%$. Mortality of weevils was recorded at twenty-four hours after treatment. Weevils were considered dead when they did not move, even when prodded with a needle. Controls for each trial consisted of pepper weevils placed in vials treated only with acetone.

Data analysis. From the data collected, the following parameters were calculated using Probit analysis (Daum 1970, Raymond 1985) for each of the seven insecticides examined: lethal concentration at $50 \%\left(\mathrm{LC}_{50}\right)$, lethal concentration at $95 \%\left(\mathrm{LC}_{95}\right)$, the corresponding confidential limits at $95 \%(95 \% \mathrm{Cl})$, the slope of the regression line including standard error, and the chi square value $\left(X^{2}\right)$. The resistance ratio $\left(\mathrm{RR}_{50}\right)$ was calculated by dividing the $\mathrm{LC}_{50}$ of each field population by that of the PWIF population for the corresponding insecticide.

\section{RESULTS}

The most toxic values of $\mathrm{LC}_{50}$, which is the most common parameter to determine toxicity of an insecticide, were observed for the carbamates methomyl and oxamyl. For methomyl, which presented the lowest doses to kill $50 \%$ of the pepper weevils, 41.4, 3.3, and $2.9 \mu \mathrm{g} / \mathrm{mL}$ were necessary for the Todos Santos, Los Planes, and PWIF populations, respectively (Table 1). For oxamyl were needed, 29.9, 17.8, and 4.4 $\mu \mathrm{g} / \mathrm{mL}$, respectively. It is important to mention that there was no significant difference in methomyl between the PWIF and Los Planes populations, though the Todos Santos population was considerably different. This can be explained by a larger area of cultivated pepper in this rural town, and a long period (not recorded) of carbamates used there.

The next higher $\mathrm{LC}_{50}$ values (Table 1) were observed for methamidophos (organophosphate) and endosulfan (organochlorine), which often are highly recommended by local agricultural advisors who regard them as very effective in the control of "wide-spectrum" pests, and some times even indicated as "friendly to beneficial insects" (Stevenson 1993, Gómez et al. 2000, Servín et al. 2006). The next 
Table 1. Insecticide toxicity to two pepper weevil populations; A. eugenii, from commercial fields, (Los Planes and Todos Santos) and, one population not exposed to insecticides (PWIF) in Baja California Sur, Mexico.

\begin{tabular}{|c|c|c|c|c|c|c|}
\hline Chemical & $N$ & $\begin{array}{c}L C_{50}(95 \% C I) \\
(\mu g / m L)\end{array}$ & $\begin{array}{c}L C_{95}(95 \% \mathrm{Cl}) \\
(\mu \mathrm{g} / \mathrm{mL}))\end{array}$ & Slope $( \pm S E)$ & $X^{2}$ & $R R_{50}$ \\
\hline \multicolumn{7}{|l|}{ Carbaryl } \\
\hline PWIF & 200 & $161.4(85.3-303.7)$ & $5452(1804.4-58626.8)$ & $1.07 \pm 0.21$ & 1.47 & - \\
\hline Los Planes & 450 & $568(341-916)$ & $11057(5134.3-41143.5)$ & $1.27 \pm 0.19$ & 1.63 & 3.5 \\
\hline Todos Santos & 450 & $2795(1451.8-4635.2)$ & $81459.2(34462.4-428380)$ & $1.12 \pm 0.20$ & 0.76 & 17.31 \\
\hline \multicolumn{7}{|c|}{ Azinphos methyl } \\
\hline PWIF & 225 & $106.2(79.5-145.2)$ & $775.4(449.7-2007.9)$ & $1.9 \pm 0.28$ & 1.51 & - \\
\hline Los Planes & 450 & $135.6(103.7-180.4)$ & $584.4(374.5-1340.5)$ & $2.59 \pm 0.44$ & 0.28 & 1.27 \\
\hline Todos Santos & 450 & $123.7(85.1-170.3)$ & $820.9(506.8-1898.3)$ & $2.00 \pm 0.31$ & 0.26 & 1.16 \\
\hline \multicolumn{7}{|l|}{ Cyfluthrin } \\
\hline PWIF & 225 & $77.8(51.8-114.3)$ & $815(446-2234.5)$ & $1.61 \pm 0.23$ & 0.96 & - \\
\hline Los Planes & 225 & $160.8(103.2-240.1)$ & $1766.7(955.7-5020.2)$ & $1.58 \pm 0.24$ & 0.56 & 2.06 \\
\hline Todos Santos & 225 & $122.3(75.0-205.0)$ & $2742.5(1106.5-15348)$ & $1.2 \pm 0.20$ & 4.62 & 1.57 \\
\hline \multicolumn{7}{|l|}{ Endosulfan } \\
\hline PWIF & 225 & $39.4(22.2-71.7)$ & $1256.1(468.7-7395.5)$ & $1.09 \pm 0.17$ & 0.45 & - \\
\hline Los Planes & 225 & $59.1(34.3-100.5)$ & $2095.7(844.3-9841.3)$ & $1.06 \pm 0.15$ & 0.22 & 1.5 \\
\hline Todos Santos & 225 & $102(59.1-183.8)$ & $3294.1(1260-17694.6)$ & $1.09 \pm 0.16$ & 0.59 & 2.58 \\
\hline \multicolumn{7}{|c|}{ Methamidophos } \\
\hline PWIF & 200 & $22.3(16.9-28.1)$ & $98.6(67.6-196.4)$ & $2.55 \pm 0.42$ & 0.73 & - \\
\hline Los Planes & 200 & $39.2(27.8-53.0)$ & $262.3(160.3-635.4)$ & $1.99 \pm 0.32$ & 1.22 & 1.75 \\
\hline Todos Santos & 200 & $24.1(17.6-35.2)$ & $158.4(89.4-422.9)$ & $2.01 \pm 0.29$ & 0.44 & 1.08 \\
\hline \multicolumn{7}{|l|}{ Oxamyl } \\
\hline PWIF & 200 & $4.4(2.2-7.6)$ & $114.5(53.2-421.7)$ & $1.16 \pm 0.18$ & 0.4 & - \\
\hline Los Planes & 200 & $17.8(10.2-30.5)$ & $536(217.1-2609.7)$ & $1.11 \pm 0.17$ & 1.14 & 4.04 \\
\hline T. Santos & 200 & $29.9(16.7-48.3)$ & $620.1(296-2244.6)$ & $1.24 \pm 0.19$ & 0.23 & 6.79 \\
\hline \multicolumn{7}{|l|}{ Methomyl } \\
\hline PWIF & 200 & $2.9(1.3-5.4)$ & $94.9(39.7-427.4)$ & $1.08 \pm 0.17$ & 0.28 & - \\
\hline Los Planes & 200 & $3.3(1.7-5.8)$ & $248.6(95.0-1228.5)$ & $0.87 \pm 0.12$ & 0.38 & 1.13 \\
\hline Todos Santos & 200 & $41.4(10.9-82.7)$ & $1766.2(717.8-13323.8)$ & $1.0 \pm 0.22$ & 0.29 & 14.27 \\
\hline
\end{tabular}

values were observed for cyfluthrin (pyrethroid), and azinphos methyl (organophosphate), while the lowest toxicity was observed for carbaryl, another carbamate insecticide with doses of 2795,568 , and $161 \mu \mathrm{g} / \mathrm{mL}$, to kill $50 \%$ of samples from Todos Santos, Los Planes, and the PWIF, respectively.

The $\mathrm{LC}_{95}$ values (Table 1) confirmed methomyl as the most toxic insecticide with the lowest dose $(94.9 \mu \mathrm{g} / \mathrm{mL})$ to kill $95 \%$ of the PWIF population. However, oxamyl and methomidophos showed similar level of toxicity with $\mathrm{LC}_{95}$ values of 114.5 and $98.6 \mu \mathrm{g} / \mathrm{mL}$, respectively, for PWIF population.

Table 1 also shows the susceptibility resistance ratios $\left(R_{50} s\right)$ for all populations in this study. The highest differences on $\mathrm{RR}_{50} \mathrm{~s}$ between the field populations (particularly Todos Santos) and the PWIF were observed in descending order for carbaryl (17.31), methomyl (14.27) and oxamyl (6.79), all of them carbamate 
insecticides. The differences on $\mathrm{RR}_{50} \mathrm{~s}$ between the populations of Los Planes and PWIF showed low values. However, also two carbamates; oxamyl and carbaryl, showed the highest values (4.04 and 3.5, respectively). Table 1 presents the slopes in the regression equation for the three populations. The slope indicates the degree of homogeneity of a population in response to a toxin (Servín et al. 2006).

\section{DISCUSSION}

Considering the $\mathrm{LC}_{50}$ values, the PWIF was indeed the most susceptible population in all of the toxicological tests, demonstrating that after two years of isolation from insecticides, the pepper weevil recovered some of its natural susceptibility. In contrast, weevils from Todos Santos were the least susceptible to almost all the insecticides, except to methamidophos, cyfluthrin, and azinphos methyl which showed greater toxicity to Los Planes weevils.

These differences in susceptibility between the two field populations can be explained by the type of insecticides used historically in each locality. Given that there are no official records of insecticide utilization in this state, one can deduce that in Los Planes there has been a tendency to use organophospates such as methamidophos and azinphos methyl, and pyrethroids such as cyfluthrin. Farmers in Todos Santos have most often used carbamates such as methomyl and carbaryl, organochlorines such as endosulfan; and smaller amounts of organophosphates and pyrethroids. Another possibility is that there is a cross-resistance to the carbamate group, which means that, the toxicological response of the weevils to them is similar because they belong to the same chemical group. Target site cross-resistance is very common, and expected with insecticides of the same toxicological group (Zalom et al. 2005). This could be a case of cross-resistance related to the proximity of other pesticides contaminated crops in both areas.

According to the slopes in the regression equation for the three populations, there is a positive correlation between slope and homogeneity (Servin et al. 2006). In general, the most heterogeneous response in resistance development was for methomyl, with values of 1.0, 0.87, and 1.08 for the populations of Todos Santos, Los Planes and the PWIF respectively. The next most heterogeneous responses were observed for the following insecticides: oxamyl, endosulfan, cyfluthrin, and carbaryl, in that order. The most homogeneous responses were for two organophosphates: azinphos methyl and methamidophos. Other experiences (Servín et al. 2006) have shown that organophosphate insecticides (methamidophos and methyl parathion) are the most homogeneous in resistance development response over organochlorine and pyrethroid insecticides.

Based on the historical management of pepper weevils in the studied localities and the differences in $\mathrm{RR}_{50}$ between our field and PWIF populations, it is likely that A. eugenii in Todos Santos has developed robust resistance to carbamate insecticides. 
However, this does not mean that our field populations have not developed resistance to other insecticides, especially considering that there is a serious lack of information about resistance for this species.

These results can be explained by differences in stability level of the different resistance mechanisms of insects to each type of insecticide. There are two major mechanisms conferring resistance to organophosphates and pyrethroids: target-site insensitivity and detoxification (Zalom et al. 2005). Organophosphates bind to and inhibit the activity of the synaptic enzyme acetylcholinesterase (AChE), resulting in disruption of the normal transmission of nervous impulses across the synapse. In resistant insects, insensitivity of the AChE to binding by organophosphates restores synaptic function even in the presence of organophosphates. Pyrethroids bind to sites on the sodium channel and disrupt the transmission of impulses along the nervous axon by holding the channels in an open position (Bradbury and Coats, 1989). Crossresistance occurs in an insect when resistance mechanisms selected in response to one insecticide also confers resistance to a second insecticide to which the insect has not been exposed. Cross-resistance among different classes having different mechanisms is viewed as a more serious problem (Zalom et al. 2005).

There is very little published information about the resistance of pepper weevil to the insecticides studied here. In this context, Genung and Osaki (1972) mentioned susceptibility to methomyl, carbaryl, and endosulfan in field evaluations. Five years later, Rolston (1977) mentioned that he found resistance of this insect to endosulfan and methomyl, also in commercial fields, causing mortalities of 15 and $65 \%$, respectively. More recently, Leibee and Capinera (1995) reported resistance of pepper weevil to fenvalerate, permethrin, and oxamyl. In BCS, Servín and Aguilar (2000) found resistance to carbaryl for a weevil population from La Paz (close to Todos Santos and Los Planes), agreeing with the present study. Given the difficulty in establishing reference line for correct resistance comparison (López 1996), Servín and Aguilar (2000) also reported a relevant result: differences in susceptibility up to 30-fold for carbaryl between Los Planes, and Benito Juarez, a very isolated community in northern BCS with very sparse use of insecticides, which could be considered a reference baseline. The relatively low levels of resistance can be explained by the isolation of each rural area, and the limited extension of crop production caused by water scarcity in this state.

According to the records of applications in the areas studied here, it is noteworthy that Los Planes presented the most critical situation, especially since methomyl and carbaryl are insecticides under official restriction (CICOPLAFEST 2000). For that reason, it is urgent that measures be taken to avoid an increase in resistance in this locality. Thus, in order to produce peppers and have a profitable margin, some tactics to manage the pepper weevil should include a combination of biological control agents (Coto 1996, Gómez et al. 2000, Carballo et al. 2001), low environmental 
impact insecticides, and entomopathogenic organisms all apply at a proper biological weevil stage (Riley and Schuster et al. 1994, Toapanta et al. 2005).

Acknowledgments. We thank Q. Dinora Guadalupe Romero, for assistance in conducting the toxicological bioassays. Orlando Lugo and Amado Cota for their technical support with the experiments and handling the specimens.

\section{LITERATURE CITED}

Azrang, M. 1976. A simple device for collecting insects. Entomologist Tidskrift. 97: 92-94.

Bernot, S. P. M. 1992. Aspectos del comportamiento y biología del barrenillo del chile Anthonomus eugenii Cano (Coleoptera: Curculionidae) aplicados al control químico de la plaga. Tesis de Maestría (Ciencias), Instituto Tecnológico de Estudios Superiores de Monterrey, Monterrey, N. L., México. 95 pp.

Bradbury, S. P., \& J. R. Coats. 1989. Comparative toxicology of pyrethroid insecticides. Rev. Environmental Contamination and Toxicology. 108: 133-177.

Bujanos, R. 1993. Barrenillo del chile. Manejo Integrado. Folleto para productores Número 1. Campo Experimental Norte de Guanajuato / Campo Experimental Bajío, Instituto Nacional de Investigaciones Forestales, Agrícolas y Pecuarias, SARH. México. 6 pp.

Cásseres, E. 1980. El chile o pimentón o ají y la berenjena. Pp. 107-123. In: E. Cásseres (Ed). Producción de hortalizas. IICA, San José, Costa Rica.

Capinera, J. L. 2005. Pepper weevil, Anthonomus eugenii Cano (Insecta: Coleoptera: Curculiondae). University of Florida. IFAS Extension. EENY-278. 6 pp.

Carballo, M., L. Rodríguez \& J. Durán. 2001. Evaluación de Beauveria bassiana para el control del picudo del chile en laboratorio. Manejo Integrado de Plagas (Costa Rica). 62: 54-59.

CICOPLAFEST. 2000. Catálogo Oficial de Plaguicidas. $481 \mathrm{pp.}$

Coto, D. 1996. El picudo del chile (Anthonomus eugenii Cano) su reconocimiento y posible manejo. Hoja Técnica No. 19. Manejo Integrado de Plagas (Costa Rica). 42: 1-4.

Daum, R. J. 1970. Revision of 2 computer programs for probit analysis. Annals of the Entomological Society of America. 16: 10-15.

Enríquez, J. \& P. Valenzuela. 1996. Evaluación de insecticidas para el control del picudo del chile Anthonomus eugenii Cano. Memorias del VI Congreso Latinoamericano y del XXXI Congreso Nacional de Entomología, Sociedad Mexicana de Entomología. Mérida, Yucatán, México. p. 119-120.

Frantz, G. \& H. C. Mellinger. 1998. Measuring Integrated Pest Management Adoption in South Florida Vegetable Crops. Proceedings of the Florida State Horticultural Society. 132: 1- 15 pp.

Genung, W. G. \& H.Y. Osaki. 1972. The pepper weevil Anthonomus eugenii Cano on the lower Florida east coast. Belle Glade. AREC Mimeo Report EV. 2 pp.

Gómez, Y., J. V. Ramírez, B. Sandoval \& A. Bolaños. 2000. Alternativas biológicas y orgánicas en el control de Anthonomus eugenii en chile picante. Manejo Integrado de Plagas (Costa Rica). 57: 74-77.

Gutiérrez, C. 1999. Evaluación de la asociación maíz - chile para el manejo de Anthonomus eugenii en Nicaragua. Manejo Integrado de Plagas (Costa Rica). 54: 73-77.

Hernández, J. \& R. González. 1992. Efecto de siete insecticidas sobre el control de picudo del chile Anthonomus eugenii Cano (Coleoptera: Curculionidae). Memorias del XXVII Congreso Nacional de Entomología, Sociedad Mexicana de Entomología. San Luis Potosí, S. L. P., México. 294-295.

Laborde, J. \& O. Pozo. 1982. Pasado y Presente del Chile en México. SARH-INIA, Publicación Especial No. 85. México. 80 pp. 
Leibee, G. L. \& J. L. Capinera. 1995. Pesticide resistance in Florida insects limits management options. Florida Entomologist. 78: 386-399.

López, M. 1996. Susceptibilidad a insecticidas en dos poblaciones de campo de adultos del barrenillo del chile Anthonomus eugenii Cano (Coleoptera: Curculionidae) procedentes de San Luis Potosí, México. Tesis de Maestría (Ciencias). Colegio de Postgraduados en Ciencias Agrícolas. Montecillo, Estado de México, México. 24 pp.

Pacheco-Covarrubias, J. J. 1985. Combata al barrenillo del chile. S.A.R.H., I.N.I.A., C.I.A.N.O., C.A.E.C.H. Desplegable para productores Núm. 4. Hermosillo, Sonora. México. 6 pp.

Pacheco-Covarrubias, J. J. 1993. Eficacia y eficiencia de azinfós metílico y paratión metílico para el control de adultos de barrenillo del chile Anthonomus eugenii, en el Valle del Yaqui, Son. CEVYCIRNO. Informe Técnico CEVY-CIFAPSON. Sonora, México. 4 pp.

Quiñones, F. J. \& A. Flores. 1991. Toxicidad de insecticidas en poblaciones de picudo del chile Anthonomus eugenii Cano (Coleoptera: Curculionidae) en el estado de Chihuahua. Pp 264. En: Memorias del XXVI Congreso Nacional de Entomología Veracruz, Veracruz, Sociedad Mexicana de Entomología.

Raymond, M. 1985. Présentation de un programme de analyse log-probit pour micro-ordinnateur. Cahiers ORSTOM, Série Entomologie Médicale et Parasitologie. 22: 117-121.

Riley, D. 1995. The pepper weevil and its management. Texas Agricultural Extension System Texas A\&M. 3 pp.

Riley, D. G. \& E. G. King. 1994. Biology and management of pepper weevil Anthonomus eugenii Cano (Coleoptera: Curculionidae): A review. Entomology (Trends in Agricultural Science). 2: 109-121.

Riley, D. G. \& D. J. Schuster. 1994. Pepper weevil adult response to colored sticky traps in pepper fields. Southwestern Entomologist 19: 93-107.

Rolston, L. H. 1977. Insecticide tests in laboratory and field against the pepper weevil, Anthonomus eugenii Cano. Journal Georgia Entomological Society. 12: 117-120.

SAGAR. 1997. Programa fitosanitario de contingencia para el control del picudo o barrenillo del chile (Anthonomus eugenii). Comité Regional de Sanidad Vegetal La Paz-Los Cabos. 13 pp.

SAGARPA. 2005. Servicio de información estadística agroalimentaria y pesquera (SIAP). http://www.siap.sagarpa.gob.mx/.

Schauff, M. E. 1986. Collecting and preserving insects and mites: Techniques and tools. USDA Systematic Entomology Laboratory, Washington, D.C. 68 pp.

Servín, R. \& R. Aguilar. 2000. Bioensayos toxicológicos en picudo del chile Anthonomus eugenii Cano (Coleoptera: Curculionidae) por exposición residual, en Baja California Sur, México. Folia Entomológica Mexicana. 109: 117-118.

Servín, R., R. Aguilar, J. L. Martínez, E. Troyo \& A. Ortega. 2002. Monitoring of resistance to three insecticidas on pepper weevil (Anthonomus eugenii) in populations from Baja California Sur, Mexico. Interciencia 27: 691-694.

Servín, R., J. L. García-Hernández, B. Murillo, A. Tejas \& J. L. Martínez. 2006. Stability of insecticide resistance of silverleaf withefly (Homoptera: Aleyrodidae) in the absence of selection pressure. Folia Entomológica Mexicana. 45: 27-34.

Stevenson, P. 1993. Eight years later, industry advertising still violates FAO code. Global Pesticide Campaigner 5 pp.

Toapanta, M. A. 2001. Population, ecology, life history, and biological control of the pepper weevil, Anthonomus eugenii Cano (Coleoptera: Curculionidae). Ph.D. dissertation, University of Florida, Gainesville. 152 pp.

Toapanta, M. A., D. J. Schuster \& P. A. Stanley. 2005. Development and life history of Anthonomus eugenii (Coleoptera: Curculionidae) at constant temperatures. Environmental Entomology. 34: 999-1008. 
Servín-Villegas, et al. Susceptibility of pepper weevil (Coleoptera: Curculionidae) to seven insecticides

Zalom, F. G., N. C. Toscano \& F. J. Byrne. 2005. Managing resistance is critical to future use of pyrethroids and neonicotinoids. http://CaliforniaAgriculture.ucop.edu.

Recibido: 21 de diciembre de 2007

Aceptado: 7 de marzo de 2008 